\title{
The Development of Online Learning Media Based Android on Students Development Subject
}

\author{
Dody Feliks Pandimun Ambarita ${ }^{1 *}$, Elizon Nainggolan ${ }^{2}$, Robenhart Tamba ${ }^{3}$ \\ ${ }^{1,2,3}$ Faculty of Science Education, State University of Medan, Medan, Indonesia \\ *dodyambarita@gmail.com
}

\begin{abstract}
The purpose of this study is to determine the form of an online learning media based android on Students Development subject and to determine how the students assessment against android application developed. This study is a research and development. Researchers use ADDIE research groove namely Analysis, Design, Development, Implementation and Evaluation. In the analysis phase, researchers conducted interview with students in Primary Teacher Education to find out the application form required in the subject of Students Development with blended learning model. Furthermore, researchers designed the initial shape and structure of the application work. After the initial shape and structure have been defined, the researchers develop android application using android software studio accordance with the application form needed by the students. The material used by researchers on android application is the material according to the syllabus of Student Development Subject and the researchers also developed a Semester Lecture Plan in accordance with the design of blended learning model. In the implementation phase, the researchers asked two experts are subject matter expert and media expert to assess the application developed. In implementing phase, the researchers also asked students from the Department of Primary Teacher Education as many as 30 people to give their assessment of the application developed including providing assessment of the implementation of online learning using android application. Media expert gives a value of 75.50 with an average of 3.41 and categorized as very feasible. For the material, the researchers asked the expert that truly understand even master the Students Development subject. Material expert provides an assessment of 59.50 with an average value of 3.71 and considered good and decent. Students give value to this application at 72.85 with an average of 3.60 and the category is decent.
\end{abstract}

Keywords: Blended Learning, Android, Students Development Subject.

\section{Introduction}

The world of education is inseparable from the learning process that includes faculty, students, and the learning environment influence each other in order to achieve the learning goals. The media is one factor supporting the achievement of learning goals. This relates to the use of appropriate media and varied in the learning process can increase the motivation to learn and can reduce the passivity of students [1].

The development of mobile technology is now so fast; one of the mobile devices that are now commonly used is a cellular phone. Almost $90 \%$ of students have a mobile phone with android platform. With the increasing number of students who have and use mobile devices, the greater the chances of the use of technology tools in education. Media that utilizes mobile 
phone technology is called mobile learning (M-Learning). M-Learning is one of the alternative development of instructional media. The presence of m-learning is intended as a complement to the learning and provide opportunities for students to learn the material that is less controlled anywhere and anytime [2,3]. Android Studio is a software to create an learning media based android that is easy to use and apply. Android Studio is a software that provides templates in making android application. Android Studio can support the process of making learning applications based on Android, Mac OS, Windows Phone, Blackberry and HTML 5.

Students Development are subject that provide supplies to the students about the students understanding in depth, as one of the basic competencies that must be mastered well by the teacher to the learner as its main focus in the provision of education and learning, relating to the characteristics learners, growth and development, the laws of development, developmental aspects, needs, developmental tasks, and the adjustment (early age, children and adolescents), means of non-test in identifying development of learners and their implications in education. Students Development subject is taught by researchers,

The purpose of this study was to determine the form of an online learning media based android on Students Development course and to determine how the student assessment against android application developed.

\section{Learning Media.}

According to Flemming in Arsyad [2,4] argues that the media often referred to the mediator that is the cause or the tools to intervene and reconcile the two parties. The term mediator media indicate the function or role of organizing an effective relationship between the two main parties in the learning process. Meanwhile, Gagne and Briggs in Arsyad [5] implicitly saying that learning media is a tool that is physically used to convey the content of learning materials, consisting of books, tape recorders, cameras, cassettes, video recorder, film, television, slide (picture frame), photographs, graphics, and computer.

\section{Mobile Learning}

The term mobile learning (m-learning) refers to the use of the device / device information technology (IT) handheld and moving, just as PDAs, mobile phones, laptops and tablet PCs, in teaching and learning. M-learning is part of the electronic learning (e-learning) so that by itself is also part of the distance learning (d-learning). Mobile learning is a unique learning because learners can access learning materials, referrals and applications relating to learning anytime and anywhere [6,9]. This will increase attention on the material being taught, makes learning more interesting, and can motivate learners towards lifelong learning.

\section{Android applications}

Android is an operating system developed for Linux-based mobile devices such as smartphones and tablet PCs. Android is the operating system (OS) mobile grow amid developing other OS. Other OS such as Windows Mobile, i-Phone OS, Symbian, and much more [7]. This OS also offers content and the optimal wealth of existing hardware devices. However, the existing OS is running prioritize core applications are built on their own without seeing considerable potential of the application of the various parties.

\section{Students Development Subject}

In every stage of human development have distinct characteristics and its own developmental tasks that are useful as a guide towards a normal development. The developmental tasks are also highly correlated with the education received by the individual. 
Education determines whether the task can be executed someone at certain times. The selfconcept and self-esteem will go down if someone does not carry out the development tasks well, because the individual would receive censure from the surrounding community, causing unhappiness for the individuals concerned. Instead of success in carrying out development tasks gives a feeling of success and happiness.

In general, the benefits of studying Students Development can be perceived by educators and learners. For Educator: a. Provides an overview of human development throughout the life span as well as the factors that influence it, which cover physical, intellectual, emotional, social and moral. b. Provides an overview of how the process of learning appropriate to the stage of development of learners. For Students: Have knowledge of the concepts of development of Students that includes individuals in carrying out developmental stages of prenatal and elderly.

\section{Research Method}

This study is research and development that is a type of research that aims to produce a specific product and test the quality of the product. Product that produced in this study is learning media based android. The research method used is ADDIE model (Analysis, Design, Development, Implementation, and Evaluation).

Data collection techniques used in this research is observation, interviews, and questionnaires. This research using descriptive analysis techniques to analyze data in ways that describe or depict the data that has been collected from the development, validators' responses for validity and students' responses in trial design for practicality [8].

\section{Results and Discussion}

This media development begins by analyzing some of the necessary requirements. These needs include: the election materials, the determination of the user (user), eligibility criteria, and software to develop android application blended learning model.

From the observation that have been made data showed that the average student has an android smartphone. It became a great potential and opportunities for the development of learning media based android.

Content that is intended in this case is learning materials of Students Development Subject based on Semester Lecture Plan (RPS) issued by the coordinator of Basic Courses Education (MKDK) Unimed. The material presented in mobile learning applications being developed are:

1) The essence of development,

2) Theory of development: Physical, Intellectual, Emotional, Language, Special Talent, Social, Moral,

3) Developmental tasks,

4) Self concept,

5) Adjustment, and

6) Individual personality 
Mobile learning application developed using Android Studio. Android Studio is an Integrated Development Environment (IDE) for developing Android applications, based on IntelliJ IDEA. This technology can be used to construct powerful hybrid mobile applications, fast, easy and also has an attractive appearance.

\section{1) Design}

This application has a main menu that consists of Classrooms, Group, Material, Video, Exercise (quiz) and a chat room. Application Log begins with a display that requests the username and password of the user. The main menu layout application (home) has five menu icons along with the name of the application's main menu. The initial view, log in, and the application's main menu.

\section{2) Development}

Virtual learning space on the application is made to resemble the app so between learners and teachers can perform two-way communication time willingly. This application is also featured instructional videos (youtube assisted) to assist learners in understanding the material. The beginning and the display form on the application login screen are not much different as contained in the application design. The logo contained in the initial appearance of the application is English language learning logo for the Faculty of Science as in Figure 1 below.

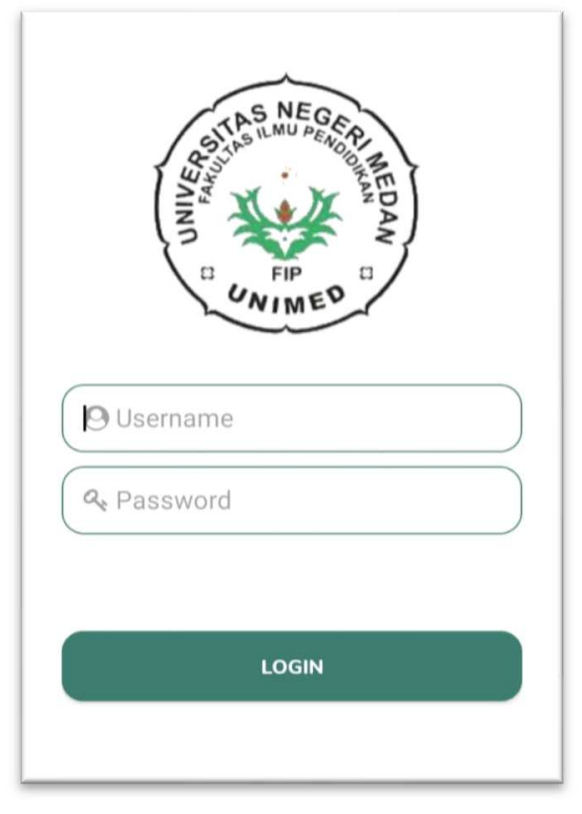

Fig 1 The Front Display (Login)

Before students attend learning online based on android, students must be registered by the lecturer by filling out the form that is already available in the application (Figure 2). Once students' account has been activated then the student can sign in to the application. 


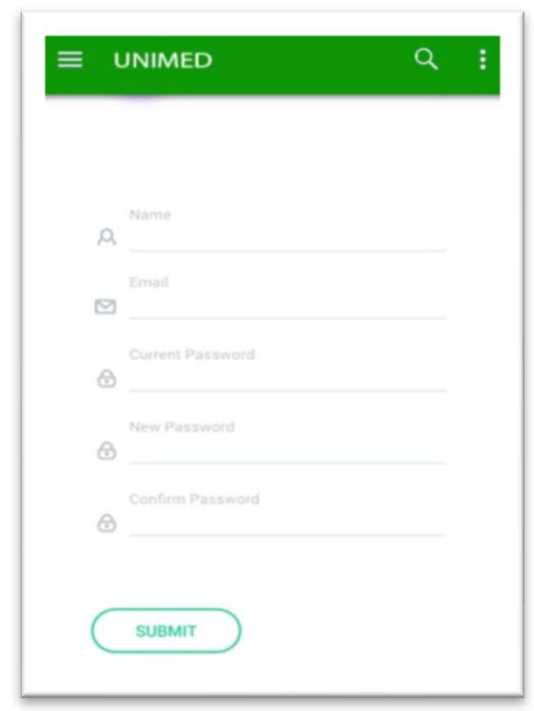

Fig 2. Student Profile Views Stuffing

Once entered into the system, students choose a study room in accordance with the classes and subjects enrolled in Study Plan Card (KRS), virtual classroom is shaped like a chat room on Whatsapp. The overall view class can be seen in Figure 3, below.

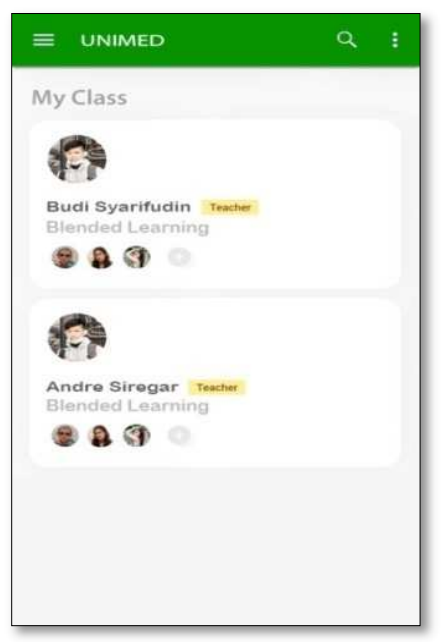

Fig 3. Display Chat Rooms

Menu quiz or exam quiz presented on the menu contents for the topics of material and accompanied by solutions answer. When the user opens the first page of the menu it will show a selection of exercises about. About the selection is divided into two sections, each section consists of 10 questions. Quizzes are given a set of exercises from various sources. Exercises that are presented in a mobile learning application are expected to help users to measure their knowledge on matters related to Students Development subject. Exercise menu page shown in 


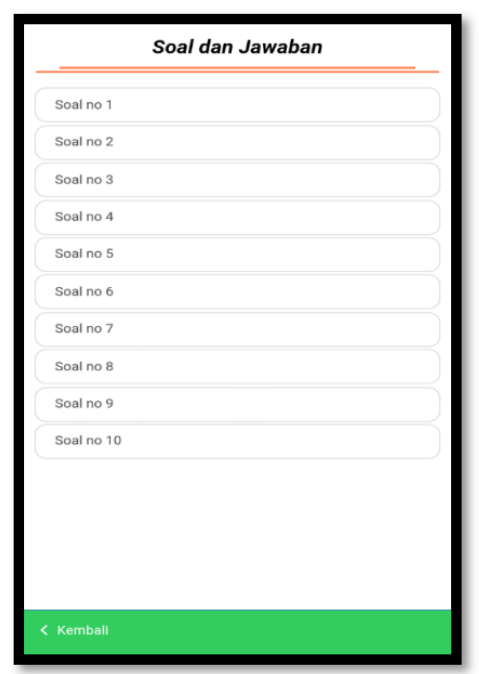

Fig 4. Quiz Menu Page

In a virtual classroom, students can view instructional videos or in the form of demonstrations connected via Youtube. Users simply select a video to be seen and confirmed to be connected with an internet connection. Video display and sound is shown in Figure 5 below.

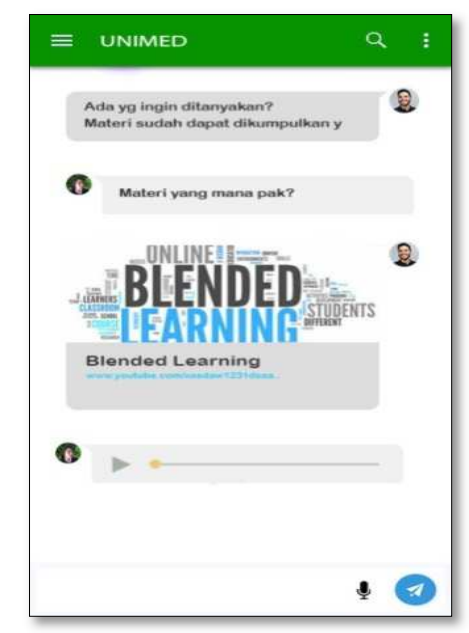

Fig 5. Player View Video and Sound.

Further to the collection activities 6 tasks, ranging from routine tasks, tasks critical book reviews (CBR), Critical Journal Review (CJR), Mini Research, Idea Engineering, and Project, in this application there is menu to upload the data tasks. Each student data upload task, lecturers will receive a notification. Upload task menu display shown in Figure 6 below. 


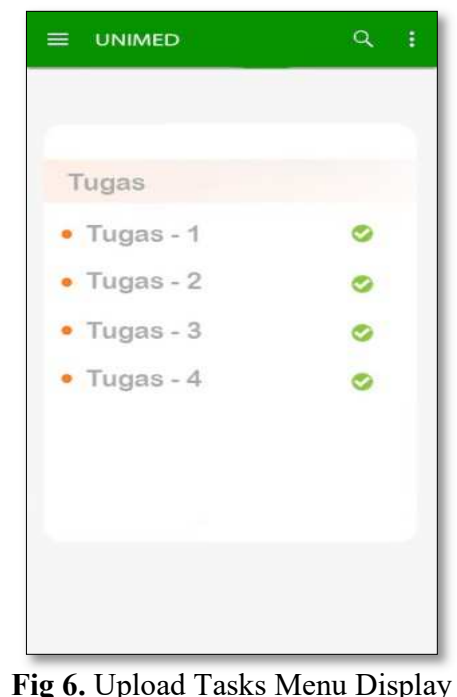

\section{3) Implementation}

At implementation phase, the product have been developed rated buy respondents. In implementation, researchers created a model of Blended Learning scenarios. Implementation of blended learning consists of 4 meetings, two are face to face meetings and two meetings online using android application.

\section{a) Media Expert Assessment Results}

A media expert respondent is the one who considered have good judgment and cons of a medium of learning. This app was tested by one person who considered by the media played a role in assessing the software engineering and visual communication. The results of media assessment are shown in Table 1 below:

Table 1. Result of Media Expert Assessment

\begin{tabular}{llc}
\hline No. & \multicolumn{1}{c}{ Item } & Score \\
\hline 1 & Description clear application & 3.50 \\
2 & The application installation process goes well & 3.50 \\
3 & Free use of the application is easy to understand & 3.50 \\
4 & Application does not take up much memory & 3.50 \\
5 & The process of loading media goes well & 4.00 \\
6 & Display layout interesting applications & 3.00 \\
7 & The composition and interesting colors used design & 3.00 \\
8 & Display design, size and layout of the proper icon & 3.50 \\
9 & Icon / button that allows users to use the media & 3.50 \\
10 & Audio files in the app runs fine & 3.00 \\
11 & The video link learning goes well & 3.50 \\
12 & Applications can be run in all versions of android & 4.00 \\
13 & Use of the font type and size are correct & 3.50 \\
14 & The use and effect of the application interface is simple and & 3.00
\end{tabular}




\begin{tabular}{llc}
\hline No. & \multicolumn{1}{c}{ Item } & Score \\
\hline & attractive & \\
15 & bug or error in the application a little & 3.50 \\
16 & Application can be easily modified & 3.00 \\
17 & Applications can be used anytime and anywhere & 3.50 \\
18 & Some or all of the application programs can be recovered & 3.50 \\
19 & Design of a display according to the user level & 3.50 \\
20 & The ease and simplicity in operation & 3.50 \\
21 & Applications can be run in all screen resolution & 3.50 \\
22 & Master application easily transferred from one phone to another & 3.50 \\
\multicolumn{2}{l}{ Total number } & 75.50 \\
Average & & 3.41 \\
Criteria & & very Decent \\
\hline
\end{tabular}

b) The Results of Material Expert Assessment

A learning material expert who assess the feasibility of respondents in terms of instructional design and content learning materials. In this study the authors define material experts are experts who truly understand how to design an interesting learning based on the material and sub-material in Students Development subject and has a science background who very related to the subject. The results of the assessment of the material shown in Table 2 below.

Table 2. Results of learning Material Expert Assessment

\begin{tabular}{|c|c|c|}
\hline No. & Item & Score \\
\hline 1 & $\begin{array}{l}\text { The material contained in the application in accordance with the curriculum } \\
\text { KKNI }\end{array}$ & 4.00 \\
\hline 2 & This application can support the achievement of learning goals & 4.00 \\
\hline 3 & This application can support the implementation of blended learning models & 4.00 \\
\hline 4 & $\begin{array}{l}\text { This application can make learners interested to learn more about the } \\
\text { teaching materials }\end{array}$ & 3.50 \\
\hline 5 & $\begin{array}{l}\text { The material contained in the application in accordance with the RPS } \\
\text { Students Development subject }\end{array}$ & 4.00 \\
\hline 6 & Applications can broaden learners & 3.50 \\
\hline 7 & This application allows students to learn independently & 4.00 \\
\hline 8 & Readability clear sentences and paragraphs & 3.50 \\
\hline 9 & $\begin{array}{l}\text { The material contained in the application are arranged in a systematic and } \\
\text { coherent }\end{array}$ & 3.00 \\
\hline 10 & $\begin{array}{l}\text { Fucking displayed in the application can help learners to understand the } \\
\text { material }\end{array}$ & 4.00 \\
\hline 11 & The video link is presented in accordance with the material & 3.50 \\
\hline 12 & Encouraging learners actively involved & 4.00 \\
\hline 13 & $\begin{array}{l}\text { Exercises given in the application is in conformity with the material } \\
\text { presented }\end{array}$ & 3.50 \\
\hline 14 & Suitability exercises with less learning objectives & 4.00 \\
\hline 15 & Uses terms that are easily understood & 3.50 \\
\hline 16 & Provide motivation / interest and curiosity of learners & 3.50 \\
\hline \multicolumn{2}{|c|}{ Total number } & 59.50 \\
\hline \multicolumn{2}{|c|}{ Average } & 3.71 \\
\hline \multicolumn{2}{|c|}{ Criteria } & very Decent \\
\hline
\end{tabular}


c) The Assessment of Student

Students are respondents who are users of these applications in the future, the authors felt it was important to ask the student assessment on mobile learning based android application. This application is tested to 30 students majoring in the 1st half of Primary School Teaching (PGSD), Faculty of Education, Unimed. Students are given a questionnaire assessment of mobile learning applications. Accumulated average learner assessment questionnaire results are shown in Table 3 below.

Table 3. The average accumulation Questionnaire Results of Students

\begin{tabular}{|c|c|c|}
\hline No. & Item & Score \\
\hline 1 & Description of the application is easy to understand & 3.50 \\
\hline 2 & The application installation process runs smoothly on my mobile phone & 3.20 \\
\hline 3 & Free use of applications easier I understand & 3.50 \\
\hline 4 & The process of loading an application running (application no hanck or jam) & 3.45 \\
\hline 5 & All navigation button goes well & 3.20 \\
\hline 6 & Size does not take up much memory applications & 3.80 \\
\hline 7 & Application easy to run & 3.80 \\
\hline 8 & Application loading process is not long & 3.50 \\
\hline 9 & Mobile learning applications to motivate me to learn & 3.30 \\
\hline 10 & $\begin{array}{l}\text { I was able to learn actively and independently use mobile learning } \\
\text { application }\end{array}$ & 3.80 \\
\hline 11 & $\begin{array}{l}\text { I enjoy learning using mobile learning applications rather than just listening } \\
\text { to the explanation from the teacher }\end{array}$ & 3.67 \\
\hline 12 & $\begin{array}{l}\text { I can understand the material in the presence of an interesting learning } \\
\text { videos }\end{array}$ & 3.60 \\
\hline 13 & I can understand the material with the help of attractive animations & 3.80 \\
\hline 14 & $\begin{array}{l}\text { I can read the text easily because of the type and size of the font used was } \\
\text { appropriate }\end{array}$ & 3.58 \\
\hline 15 & I can learn easily because the material is presented clearly & 3.80 \\
\hline 16 & I can use the buttons with ease & 3.84 \\
\hline 17 & The material presented in easy application I understand & 3.80 \\
\hline 18 & $\begin{array}{l}\text { Exercises helped me measure my understanding on the kinetic theory of } \\
\text { gases }\end{array}$ & 3.80 \\
\hline 19 & $\begin{array}{l}\text { With mobile learning application I get a deeper knowledge about the } \\
\text { material the kinetic theory of gases }\end{array}$ & 3.50 \\
\hline 20 & $\begin{array}{l}\text { I like the look of this mobile learning applications because it has a matching } \\
\text { color composition }\end{array}$ & 3.60 \\
\hline 21 & I was able to master the use of mobile learning application media with ease & 3.48 \\
\hline 22 & I could use mobile learning application anywhere and anytime & 3.80 \\
\hline \multicolumn{2}{|r|}{ Total number } & 72.85 \\
\hline \multicolumn{2}{|c|}{ Average } & 3.60 \\
\hline \multicolumn{2}{|c|}{ Criteria } & VeryDecent \\
\hline
\end{tabular}

\section{4) Evaluation}

The evaluation was done in order to improve mobile learning applications. In this study, improvements were summarized based on the suggestions and criticisms of the respondents were divided into three aspects, namely, software engineering, instructional design and visual communication. 


\begin{tabular}{lcl}
\hline \multicolumn{1}{c}{ Aspect } & \multicolumn{1}{c}{ Criticism and suggestions } \\
\hline Software Engineering & 1 & $\begin{array}{l}\text { This application should have color settings menu so } \\
\text { that students can change the background color as } \\
\text { they wish. } \\
\text { The good form of display is designed more } \\
\text { attractive again. }\end{array}$ \\
\hline Instructional Design & 1 & $\begin{array}{l}\text { Content material needs to be added, especially the } \\
\text { explanation in the form of images. }\end{array}$ \\
& 2 & $\begin{array}{l}\text { Enrich reference teaching materials } \\
\text { The use of communicative language } \\
\text { Make learning videos related to the moral and } \\
\text { emotional development through socio-dramas } \\
\text { approach. }\end{array}$ \\
\hline Visual & 1 & $\begin{array}{l}\text { Design re-shape the look on the veranda with a } \\
\text { more interesting theme. } \\
\text { The good video contained in the application can be } \\
\text { downloaded by the students. }\end{array}$ \\
\hline
\end{tabular}

\section{Discussion}

The development of mobile technology is now so fast, one of the mobile devices that are now commonly used is a cellular phone. Almost $90 \%$ of students have a mobile phone with android platform. With the increasing number of students who have and use mobile devices, the greater the chances of the use of technology tools in education.

Media that utilizes mobile phone technology is called mobile learning (M-Learning). MLearning is one of the alternative development of instructional media. The presence of $\mathrm{m}$ learning is intended as a complement to the learning and provide opportunities for students to learn the material that is less controlled anywhere and anytime $[3,4]$.

This media development begins by analyzing some of the necessary requirements. These needs include: the election materials, the determination of the user (user), eligibility criteria, and software to develop android application learning blended learning models. After that the next stage is draft structured in a flow diagram that contains forms and display features contained in the application. The development stage is the stage of manufacture of mobile learning applications. In making the application is tailored to the design plan.

Study materials and the material presented in the course is based on the development of learners in the learning activity undertaken. In general, the study material of this course include: The nature of development, development theory, development: Physical, Intellectual, Emotional, Language, Special Talent, Social, Moral, tasks development, self-concept, selfadjustment, and individual personality [6].

Once the finished product is developed then a subsequent implementation phase. Pilot implementation phase containing products have been developed to a number of respondents. In implementation, researchers created a model of learning scenarios Blended Learning. Implementation of blended learning consists of 4 meetings; two are face to face meetings and two meetings online using android application.

All respondents were identified in this study have their respective roles in providing an assessment of the feasibility of applications., Ranging from media experts, materials and respondents who were students taking Students Development subject. This app was tested by one of the experts who assess media that play a role in assessing the software engineering and 
communications media visual. The expert give a value of 75.50 with an average of 3.41 were categorized as very feasible. For the material, the researchers asked the expert appraisal that truly understand even mastered the course Students Development subject. Media experts provide an assessment of 59.50 with an average value of 3.71 and considered good and decent.

Students are respondents who are users of these applications in the future, the authors felt it was important to ask the student assessment on mobile learning applications. This application is tested to 30 students majoring in the 1st half of Primary School Teaching (PGSD), Faculty of Education, Unimed. Students give value to this app at 72.85 with an average of 3.60 is the decent category

In addition to providing an assessment, experts and students are required to provide feedback and ideas to the researchers. Both experts and students give us some feedback that serves as a reference for evaluation researchers against the application. The average response from the respondents is software engineering, instructional design and visual communication. After the researchers pooled the results of respondents and receive responses, perform the repair on the android app.

\section{Conclusion.}

Based on the purpose of research, the results of the analysis and development of data contained in this study the conclusions of this study are translated as follows:

1) This media development begins by analyzing some of the necessary requirements. These needs include: the election materials, the determination of the user (user), eligibility criteria, and software to develop android applications online learning. After that the next stage is draft structured in a flow diagram that contains forms and display features contained in the application. The development stage is the stage of manufacture of mobile learning applications in accordance with the design plan.

2) This app was tested by one of the experts who assess media that play a role in assessing the software engineering and visual communication. Media experts give a value of 75.50 with an average of 3.41 were categorized as very feasible. For the material, the researchers asked the expert appraisal that truly understand even mastered the Students Development subject. Media experts provide an assessment of 59.50 with an average value of 3.71 and considered good and decent.

3) This application is tested to 30 students majoring in the 1st half of Primary School Teaching (PGSD), Faculty of Education, Unimed. Students give value to this app at 72.85 with an average of 3.60 is the decent category. During the implementation of blended learning is learning two face to face meetings and two meetings online students to look more interested in participating in student learning and much freer to express questions or opinions.

As a follow up of the results of research and development that have been implemented the suggestions of researchers are

1) The lecturers should develop online learning media guided by the technical and teaching approaches in the course of teaching.

2) The lecturers should undertake a learning model for blended learning based on observation of researchers, the learning model of blended learning and online 
learning media use is very effective and well used to increase motivation and student learning outcomes.

\section{References}

[1] Hardianto, Deni. Media Education as a Means of Effective Study. Scientific Learning magazine 1, Vol. 1. Pg 95-104. (2005).

[2] Arsyad, Azhar. Learning Media. Jakarta: King Grafindo Persada. (2011).

[3] Sanjaya, Vienna. Learning Media Strategy Process Oriented Education Standards. Jakarta: Kencana Prenamedia Group. (2011).

[4] Huda, Arif Akbarul. Live Coding! 9 Applications Homemade. Yogyakarta: ANDI. (2013).

[5] Personally, BA. An important step to design effective learning activities and quality. In Model Design Learning System. Jakarta: Dian Rakyat. (2009).

[6] Purwantoro, Sugeng, et al. Mobile SearchingSAT Attractions Pekanbaru Using Location Base Services (LBS) Android based. Journals Politeknik Caltex Riau. (Vol 1 hlm177). http://www.pdii.lipi.go.id/wp-content/uploads/2014/03/Seminar-NasionalInfonnatika-_SNlf2013. Retrieved on May 26, 2019 at 20:00. (2013).

[7] Satyaputra and Arita. Beginning with ADT Android Programming Bundle. Jakarta: Elex Media Komputindo. (2014).

[8] Sugiyono. Quantitative Research Methods, Qualitative and $R \& D$ (2016th ed.). Bandung: Alfabeta. (2013).

[9] Susilana, Rudi, and Riana, CEPI. Media Learning: Reality, Development, Utilization and Assessment. Bandung: Discourse CV Prima. (2009). 